\title{
Effect of Smoke Drying on Proximate Composition and Some Heavy Metals in Shrimp and Oyster from Buguma Creek, Rivers State, Nigeria
}

\author{
Abu OMG* and Eli NP \\ Department Of Fisheries, Faculty of Agriculture, University Of Port Harcourt, Choba, Rivers State, Nigeria.
}

Received: January 24, 2018; Accepted: February 12, 2018; Published: February 26, 2018

.*Corresponding author: Abu OMG, Department Of Fisheries, Faculty of Agriculture, University of Port Harcourt, Choba, Rivers State, Nigeria, Tel: +2348037112328; E-mail: onisokyetu@yahoo.com

\begin{abstract}
This study was carried out to determine the proximate composition and some heavy metals (Lead, Zinc, Copper, Cadmium ) accumulation in shrimps and oysters from Buguma creek and to evaluate to what extent the changes in proximate composition and these heavy metals accumulation in shrimp (Penaeus notialis) and oyster (Crassostrea gasar) before and after smoke drying. Hot smoking method was used. The values obtained from proximate analysis of smoke dried shrimps and oysters were moisture $(14.90$ and 25.90$) \%$, Ash (12.64 and 8.35) \%, Protein (51.17and 56.41) \%, Fat (10.13 and 6.93) \%, Fiber (4.59\% and $1.03 \%)$ and carbohydrate (2.22 and 3.81) \% respectively. Data was analyzed using ANOVA and t-test. Results showed a significant difference $(\mathrm{p}<0.05)$ between the fresh and smoked samples. Heavy metal accumulation of smoke dried shrimp and oyster were Zinc ( 0.11 and 0.86$)$ ppm, copper (1.04 and 1.82) ppm, lead (0.12 and 0.50) ppm and Cadmium (0.30 and 0.21 ppm respectively. There was no significant difference of the fresh and smoke dried shrimp and oyster. The results also showed an increase in the proximate parameters after smoke drying except moisture. Zinc, lead and cadmium were within the W.H.O. permissible limit but copper was above the limit.
\end{abstract}

Key words: Proximate analysis; oyster; shrimp; heavy metals;

\section{Introduction}

In Nigerian Agricultural development matrix, the fisheries sector is important as it serves as a very important source of protein and also a means of livelihood to many Nigerians. The fisheries sector is estimated to contribute $3.5 \%$ of Nigerian's GDP and provides direct and indirect employment to over six million people Trade invest Nigeria [1]. According to FAO [2], per capital consumption of aquatic products has increased drastically in the last 10 years. Among the range of shell fish, shrimp and oysters are the most important species accounting for more than $70 \%$ of the total earnings of marine export in developing countries of the world [3]. Shrimp as well as oysters are very nutritious as they constitute desirable components of a healthy diet such as protein, minerals and vitamins. Shrimps are highly relished and are among the leading priced seafood on the global menu [4]. With the steady increase in rates of shrimp consumption in the developed world, especially in the US, Europe and Japan, it is increasingly becoming obvious that per capita shrimp intake probably correlates positively with economic growth [5].

Nigeria is among tropical countries endowed with rich shrimp resources. According to Dublin-Green and Tobor [6], the coastal waters of Nigeria are characterized by abundance of important living resources including shrimps, predominantly members of the family penaeidae. Nigeria is one of the tropical countries that export shrimps to developed countries like USA, Japan, and some European nations. With a production capacity of 12,000 MT annually, Nigeria's shrimps are at present entirely wild caught from the Niger Delta. Nigeria has a coastline of approximately $853 \mathrm{~km}$, over $70 \%$ of which lies in the delta; the surface area of the continental shelf is $46,300 \mathrm{~km} 2$ while the Economic Exclusive Zone (EEZ) covers an area of 210,900km2 [7]. Farfantepenaeus notialis (the pink shrimp) contributes greater proportion of shrimp in both small scale and large scale fisheries sectors in Nigeria. This is in line with the pattern of global production. Penaeid shrimps are, in terms of volume of catch and value per unit catch, one of the most important fishery resources worldwide [8]. These shrimps constitute a major part of worldwide fisheries catch, which ranged from 2.1 to 2.5 million MT annually in 1993-1997 [9].

Opara and Jufaili [10] reported high incidence of fish losses as one of the major impediments to the realization of government goal towards increasing the contribution of the sector to the overall national economy. This is because post-harvest losses in fish are represented by a net reduction in the amounts of nutrients potentially available to consumers either by direct physical loss or nutritional loss [11]. It is common knowledge that shell fishes generally are more perishable than fin fishes. These factors have effect on consumer acceptability, commercial value and income of fishermen [12]. Among the sources of good quality protein food such as beef, mutton, chicken and others, fish is the most perishable [13]. 
Considering the many species of fish and shell fish available, the number of ways in which they may be processed, it is obvious that fishery products are prepared in various ways which may affect the nutrient value of the end product. There is therefore the need to know the nutritional value of the processed product in compares with the unprocessed ones since there is great indecision in choosing what product to consume in terms of nutritional quality. Shellfish is of much value in Rivers State and most parts of Nigeria but because it is highly perishable and some people prefer it smoked, the need to smoke dry it becomes inevitable. Proper handling and processing of fresh shrimp and oyster to reduce spoilage and post-harvest losses is very important. Hence, the aim of this study is to determine the proximate composition and heavy metal accumulation of oyster and shrimp before and after smoke drying as most processors do. This study will give information to consumers on the varying proximate composition and heavy metal accumulation of the fresh and smoked samples, so as to help them in better choice making.

\section{Materials and Methods}

\section{Study Area}

The study was carried out in Buguma Creek, Rivers State which has a regular supply of oysters and shrimp from the wild where oyster and shrimp were in abundance. The Buguma Creek is located Southeast of the Niger Delta between longitude $6^{\circ} 47^{\prime} \mathrm{E}$ and $6^{\circ} 59^{\prime} \mathrm{E}$, and latitude $4^{\circ} 31^{\prime} \mathrm{N}$ and $4^{\circ} 59^{\prime} \mathrm{N}$ in Asari-Toru Local Government Area of Rivers State. The Buguma Creek system consists of the main creek channel and associated interconnecting creeks, which interconnect and surround Buguma communities [Figure 1].

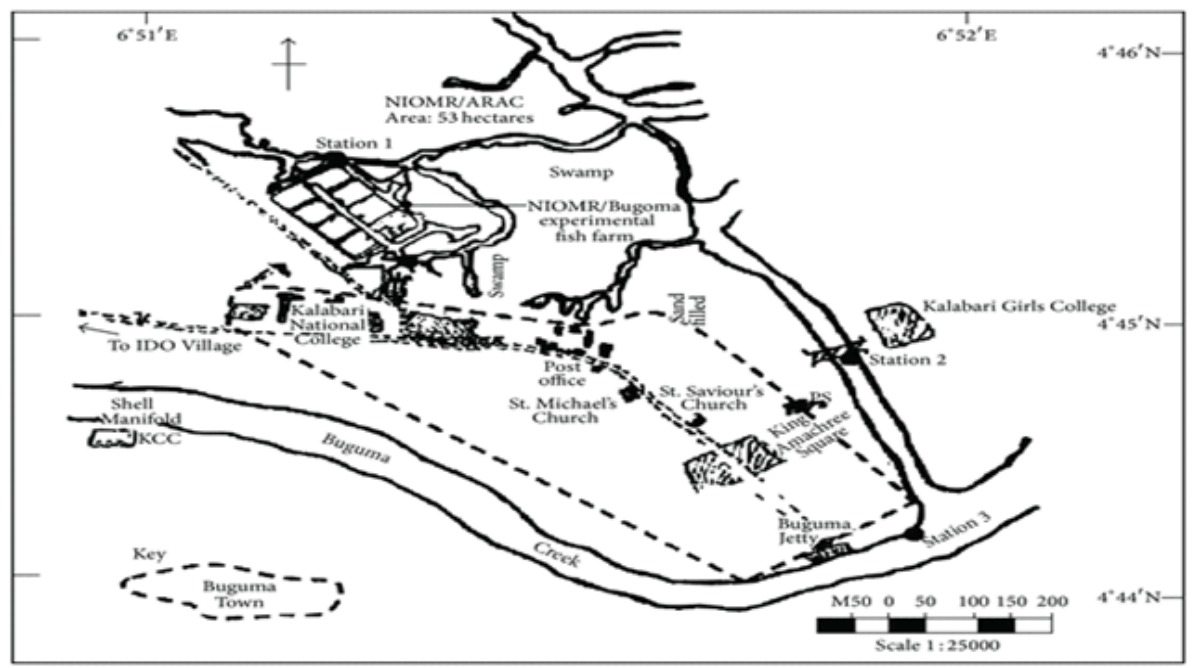

Figure 1: Map showing Buguma creek

\section{Collection of Sample}

The samples of shrimps (Penaeus notialis) and oysters (Crassostrea gasar) were purchased from fishers at the landing site in Buguma Creek. One kilogram of shrimps and one kilogram of oyster flesh were weighed out for the project.

\section{Preparation of sample}

Fresh oyster's flesh was obtained by cracking open the shell with a hammer and the flesh collected with kitchen knife as done by Salah et al [14]. Five hundred grams (500g) of oyster and shrimp were transported in a labeled transparent plastic container containing ice to NAFDAC laboratory for analysis. The other portion was transported in a container containing ice for smoking in Buguma.

\section{Smoking}

The smoking treatment adopted was the "hot smoke drying". At a temperature range $40-60^{\circ} \mathrm{C}$. Shrimps were laid out on an elevated platform of wire mesh supported by a semi-circular frame work of perforated metal drum. Smoking will require low heat which will be regulated by the amount of wood used as the processors do. During smoking, after about 20 minutes the shrimps are turned upside down by

Putting another wire mesh on it and turning the mesh upside down then smoking continued for another 25 minutes until a brownish pink colour was observed. Oysters when harvested are usually attached to a substrate usually a stick so they were roasted for about 2- 4 minutes for the bivalve to open and the oyster meat was removed using kitchen knife. The oyster meat was smoked following the same smoking process as that of the shrimp described earlier, but the colour observed was brownish.

\section{Sun drying and proximate composition Analysis}

The smoked dried shrimp and oyster were further sundried to avoid clogging together as that will result in mold infestation. To achieve this, they were placed in rectangular plastic tray covered with a net to avoid flies and other insect. Samples were dried from 12 noon to $2 \mathrm{pm}$ with an ambient temperature and allowed to cool 
indoors for about one hour. The samples were then packaged separately in a labeled transparent plastic container and taken to NAFDAC Port Harcourt for analysis. The proximate compositions of the samples collected were determined following the AOAC [15] methods.

\section{Data Analysis}

Obtained data of fresh and smoked shrimp and oyster was analyzed by expressed as mean values + standard deviation (SD). The differences between the mean values were calculated using one-way analysis of variance (ANOVA) using SPSS statistics software and t-test (using Premier V.3.01)

\section{Results}

\section{Proximate composition of Shrimp}

Table 1 gives a summary of the proximate composition of fresh and smoked Shrimp. From the table, the values of proximate composition of Smoked oyster were higher than that of fresh oyster except moisture which was lower in smoked shrimp. Table 2 gives a summary of the proximate composition of fresh and smoked Oyster. From the table, the values of proximate composition of Smoked oyster were higher than that of fresh oyster except moisture which was lower in smoked Oyster. Table 3 shows the heavy metals content variation of fresh and smoked oyster. The results indicated an increase in Zinc, Copper, and Lead and a decrease in Cadmium after smoking. While Table 4 shows the heavy metals content variation of fresh and smoked shrimp. It is observed that copper and Cadmium content of fresh shrimp increased after smoking while Zinc and Lead decreased after smoking.

Table 1: Proximate composition of Fresh and Smoked Shrimp P. notialis (Mean \pm SD)

\begin{tabular}{|c|c|c|}
\hline $\begin{array}{c}\text { Proximate Composition } \\
(\%)\end{array}$ & Fresh Shrimp & Smoked Shrimp \\
\hline Moisture & $56.37 \pm 0.21$ & $14.90 \pm 0.16$ \\
\hline Ash & $1.64 \pm 0.02$ & $12.64 \pm 0.00$ \\
\hline Protein & $26.48 \pm 0.08$ & $51.17 \pm 0.02$ \\
\hline Fat & $8.26 \pm 0.03$ & $10.13 \pm 0.01$ \\
\hline Carbohydrate & $6.27 \pm 0.12$ & $6.53 \pm 0.01$ \\
\hline
\end{tabular}

Table 2: Proximate composition of Fresh and Smoked Oyster (Crassostrea gasar)

\begin{tabular}{|c|c|c|}
\hline $\begin{array}{c}\text { Proximate Composition } \\
\text { (\%) }\end{array}$ & Fresh Oyster & Smoked Oyster \\
\hline Moisture & $70.27 \pm 0.14$ & $25.09 \pm 0.01$ \\
\hline Ash & $2.08 \pm 0.02$ & $8.35 \pm 0.04$ \\
\hline Protein & $20.65 \pm 0.03$ & $56.41 \pm 0.02$ \\
\hline Fat & $4.02 \pm 0.01$ & $5.32 \pm 0.04$ \\
\hline Fiber & $0.95 \pm 0.11$ & $1.03 \pm 0.12$ \\
\hline Carbohydrate & $2.22 \pm 0.08$ & $3.81 \pm 0.17$ \\
\hline
\end{tabular}

\begin{tabular}{|c|c|c|}
\hline \multicolumn{3}{|c|}{ Table 3: Heavy Metals Composition in Fresh and Smoked Oysters } \\
\hline Parameters & Fresh Oysters & Smoked Oysters \\
\hline Zinc & $0.11 \pm 0.05^{\mathrm{b}}$ & $0.86 \pm 0.07^{\mathrm{a}}$ \\
\hline Copper & $0.98 \pm 0.09^{\mathrm{a}}$ & $1.32 \pm 0.02^{\mathrm{b}}$ \\
\hline Lead & $0.20 \pm 0.02^{\mathrm{b}}$ & $0.50 \pm 0.03^{\mathrm{a}}$ \\
\hline Cadmium & $0.04 \pm 0.01^{\mathrm{b}}$ & $0.21 \pm 0.06^{\mathrm{a}}$ \\
\hline
\end{tabular}

Table 4: Heavy Metals Composition in Fresh and Smoked Shrimps

\begin{tabular}{|c|c|c|}
\hline Parameters & Fresh Shrimp & Smoked Shrimp \\
\hline Zinc & $0.25 \pm 0.02^{\mathrm{b}}$ & $0.11 \pm 0.04^{\mathrm{a}}$ \\
\hline Copper & $1.04 \pm 0.01^{\mathrm{a}}$ & $1.13 \pm 0.04^{\mathrm{b}}$ \\
\hline Lead & $0.50 \pm 0.05^{\mathrm{b}}$ & $0.12 \pm 0.03^{\mathrm{a}}$ \\
\hline Cadmium & $0.90 \pm 0.02^{\mathrm{b}}$ & $0.30 \pm 0.06^{\mathrm{a}}$ \\
\hline
\end{tabular}

\section{Discussion}

\section{Proximate composition of Shrimp}

The Protein mean value of fresh shrimp sample was $26.48 \%$ as compared to dry weight of $51.17 \%$. This value (dry weight) is comparable to Macrobrahium scariculum (56.75\%) [16]. Oyster had a mean value of $56.41 \%$ after smoking which was far higher than the result gotten by Judith \& Jennny [17] for Crassostrea virginica for fresh sample they arrived at $8.57 \%$ and cooked at $12.25 \%$.based on dry weight, protein values were not significantly different $(\mathrm{p}<0.05)$. This observation was due to the removal of moisture arising from the smoking process. Ash content in smoked shrimp P. notialis was $12.64 \%$ compared to the value obtained in the fresh sample of $1.64 \%$. This result is comparable but lower than research findings by Bello [18,] for smoked dried P.notialis. In oyster according to this study, ash content increased after smoking from 2.08 to $8.35 \%$ which is similar but comparable to result by Judith \& Jennny [17] who obtained $1.04 \%$ in fresh sample and 1.94 in cooked sample of Crassostrea virginica. The increase in ash content is as a result of moisture lost during the smoking process.

Moisture content from table 2 mean value for oyster is $70.27 \%$ as compared to smoked sample of $25.09 \%$. This result is comparable but lower than result from a study done by Judith \& Jenny [17] for Crassostrea virginica $82.20 \%$ fresh sample and $70.96 \%$ for cooked oyster sample. In shrimp from Table 1 the mean moisture content for shrimp was $53.37 \%$ as compared to smoked shrimp of $14.09 \%$.The reduction of moisture of both samples was as a result of heat generated during smoking process. The result is similar but higher than research finding done by Bello [18]. Carbohydrate content in fresh and dry forms due to the research is similar and agreed with the deductions [19], which is stated low carbohydrate in marine animals was due to the fact that glycogen does not contribute much to reserves in the body. Fiber content in fresh shrimp according to the study was $1.20 \%$ compared to smoked shrimp of $4.59 \%$. The value smoked shrimp was relatively higher and compared or similar to a work done by Shehu et al [20]. 
Content of heavy metals in raw and smoked shrimp and oyster in shrimp, $\mathrm{Zn}(0.11 \mathrm{ppm})$ and $\mathrm{Pb}(0.12 \mathrm{ppm})$ content were generally lower after smoking in the muscle of smoked shrimp. There was no significant difference in the Lead and Zinc content between the raw and smoked shrimp. In oyster, the level of $\mathrm{Zn}$ and $\mathrm{Pb}$ increased from $0.10 \mathrm{ppm}$ in fresh oyster to $0.86 \mathrm{ppm}$ in smoked oyster for $\mathrm{Pb}$ from $0.20 \mathrm{ppm}$ in fresh oyster to $0.50 \mathrm{ppm}$ in smoked oyster. These values were within the WHO permissible limit which is $100 \mathrm{ppm}$ [21]; the reason for the reduction in $\mathrm{Zn}$ level after smoking could be due to evaporation in the cause of smoking. Copper and Cadmium increased in smoked shrimp from $1.04 \mathrm{ppm}$ to $1.13 \mathrm{ppm}$ and 0.09 to 0.03 respectively. The level of Copper in oyster increased from $0.98 \mathrm{ppm}$ in fresh sample to $1.32 \mathrm{ppm}$ in smoked sample and Cadmium from $0.04 \mathrm{ppm}$ to $0.21 \mathrm{ppm}$. These values of cadmium despite the increase as a result of smoking were below the international standard of $2 \mathrm{ppm}$ in shell fishes [21]. Copper was above the international limit of 1ppm [21].

The general trend observed in this work is increase in nutritive qualities such as protein, lipid, fiber and carbohydrate content of shrimps and oysters as they were subjected to smoke drying method and the reverse was observed in the moisture content which significantly reduced during the smoking process. The carbohydrate and the crude fiber in both smoked shrimps and oysters were significantly low. This trend has also been reported for many species of fish, when smoke dried. The positive effect of heat intensity on the shelf life of smoked products has been reported by several researchers [22-24]. The components in the wood/charcoal via pyrolysis are broken down in the process of burning to form smoke, thus it gives the fish a unique aroma and improves its taste and colour. This is due to the presence of a range of phenolic compounds, nitrites and formaldehyde present in the smoke [24]. In view of the low levels of heavy metals got from the smoked fish samples analyzed in this study, evaluation should be carried out periodically in order to ascertain when the levels of heavy metals is above the acceptable limit, for safe consumption as these metals could be passed to humans and predispose consumers to possible health hazard associated with the consumption of these metals

\section{Conclusion}

The results of this study revealed that smoke drying of shrimp (Penaeus notialis) and oyster (Crassostrea gasar) the reduction in moisture content increased the nutrient value and the denaturation effect of smoking increases the level and digestibility of protein and hence the availability of some essential amino acids. It was observed that despite the changes in heavy metal composition, Zinc, Lead and cadmium were below the WHO permissible standard making them safe for consumption but copper was higher. With the above conclusion it is recommended that: Industrial waste or effluent should be treated before being discharged into the water body so as to reduce the level of heavy metals especially copper and its harm in the human body such as necrosis in the kidney and brain, gastrointestinal distress, low blood pressure etc.

\section{References}

1. TIN, Trade invest Nigeria. Investment Opportunities in Nigeria. Africa Investment Publishing (AIP), Abuja. 2010; 3p.

2. FAO. Food and Agriculture Organizations of the United Nations. Present and future markets for fish and fish products from smallscale fisheries - case studies from Asia, Africa and Latin America. FAO Fisheries Circular. 2008;87 p.

3. Akinrotimi OA, Edun OM, Ibama JEW .The roles of brackish water aquaculture in fish supply and food security in some coastal communities of Rivers state, Nigeria. International Journal of Agriculture Science and Food Technology. 2015;1(1):12-19.

4. Zabbey N . Smallscale Shrimp Fisheries in Nigeria. CEHRD Technical Report .2007;64(2):22-32.

5. Zabbey N . Shrimp Farming in Nigeria: Implication for Mangroves and Rural Livelihood in the Niger Delta. In: Akinbode O, Abah B and Jakpor (editors) Global Hunger, Is Food for Man or Machine? ERAction (Quarterly Magazine of Environmental Rights Action/ Friends of the Earth, Nigeria) May-August. 2008:19- 21.

6. Dublin-Green CO, Tobor JG. Marine Resources and Activities in Nigeria. NIOMR Technical paper.1992.

7. World Resources Institute (1990). World Resources (1990 - 1991), 385. P2

8. Ronnback P. The ecological basis for economic value of seafood production supported by mangrove ecosystems. Ecological Economics. 1999;29(2):235-252. Doi.org/10.1016/S0921-8009(99)00016-6

9. FAO. FAO Yearbook: Fisheries Statistics, Capture Production. Rome.1999:84p.

10. Opara LU, Al-Jufaili SM. Status of fisheries Post Harvest Industry in the Sultanate of Oman: Part 1 Quantification of fresh fish losses. Journal of Fishery International.2006;1(2):144-149.

11. Daramola JA, Fasakin EA, Adeparusi, EO. Changes in physicochemical and sensory characteristics of smoke dried fish species stored at ambient temperature. African Journal of Food Agriculture, Nutrition and Development. 2007;7(6):25-30.

12. Bostock TW, Walker DJ, Wood DJ . Reduction of Losses in Cured Fish of the Tropics; Guide for Extension Workers. Tropical Development and Research Institute, London: 1987;204(98):105

13. Ames GT , Clucas J, Paul, Susan Scott. Post harvest losses of fish in the tropics. National Research Institute Technical Report of the Tropical Products. 1991;1(60):44-52.

14. Salah S, Nawzet B, Naima, T. Comparative Effect of Different Smoking Process on Biochemical, Microbial and Sensory Characteristics of Pacific Oyster Crassostrea Gigas. Journal of Food Technology. 2013;11(2):22-29.

15. AOAC Official Methods of Analysis Ch 33.2.60, method, 2000;962:14.

16. Dinakaran G K, Soundarapandian P and Tiwary AK. Nutritional status of Edible Palaemonid Prawn Macrobrachium scabriculum . Eur. Journal of Applicable Science. 2010;2:30-36.

17. Judith K, Jenny M . Proximate composition, energy, faty acid, sodium and cholesterol content of fin fish, shell fish and their products. NOAA Technical Report NMFS: 1987;2(4):13-16.

Citation: OMG A, Eli NP (2018) Effect of Smoke Drying on Proximate Composition and Some Heavy Metals in Shrimp and Oyster from Buguma Creek, Rivers State, Nigeria. Int J Poul Fish Sci .2(1):1-5. DOI: 10.15226/2578-1898/2/1/00108 
18. Bello BK. Effect of Processing Method on the Proximate and Mineral Composition of Prawn (Peanaeus notialis). Journal of Global Biosciences. 2013;2(2):42-46.

19. Abu, OMG, Akinrotimi OA. Effects of Fish processing on nutritive values of fish. Advances in Arts, Social Sciences and Education Research. 2012;2(1):41-46.

20. Shehu LA, Ayodele B, Abubakar, B, Oluwafemi D O and Beatrice OB. Effect of Hot Smoking and Sundrying Processes on Nutritional Composition of Giant Tiger Shrimp (Penaeus monodon, Fabricus, 1798). Journal of Food Nutition Science. 2013;63(4):227-237. DOI:doi. org/10.2478/v10222-012-0093-1
21. Choi YY. International / National Standards for Heavy Metals in Food. Journal of Food. 2011;4(2):2-3.

22. Ogbonnaya M, Shaba, IM. Effects of drying methods on proximate composition of catfish (Clarias gariepinus). World J Agric Sci. 2009;5(1):114-116

23. Akinwumi FO. Effects of smoking and freezing on the nutritive value of African mudcatfish, Clarias gariepinus (Burchell 1822). J of Agric Sci. 2014;6(11):143-149.

24. Abolagba OJ. And Osifo, SJ. The effect of smoking on the chemical composition and keeping qualities of catfish (Heterobranchus bidorsalis),using two energy sources. J Agric Forestry and Fish.2004;51:27-30. DOI: 10.13140/RG.2.1.1121.3928 